\title{
ANALISIS PELAYANAN DI MAL PELAYANAN PUBLIK TERHADAP PEMBERDAYAAN MASYARAKAT MELALUI USAHA MIKRO, KECIL DAN MENENGAH (UMKM) KERAJINAN KERANJANG DI DESA GAPURA TIMUR KABUPATEN SUMENEP
}

\author{
Iffah Nurlaily ${ }^{1}$, Endang Widyastuti ${ }^{2}$ \\ ${ }^{12}$ Program Studi Manajemen Fakultas Ekonomi Dan Bisnis \\ Universitas Wiraraja Madura

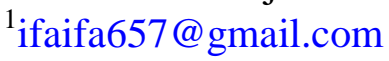

\begin{abstract}
Empowerment is a way, a process, an act of empowering. So that community empowerment can be interpreted that the way society processes. In this case, the community proceeds in the UMKM. The process referred to here is a process to improve the economic situation of surrounding communities that is unstable. This research uses a qualitative approach with a descriptive method. This research is located in the East Gapura Village, Sumenep Regency. Data collection techniques used through interviews, observation and documentation. This research will explain how community empowerment through UKM Craft Basket in the East Gapura Village, Sumenep Regency. The results obtained from this study indicate that the process of community empowerment through MSME Basket Craft is going well. The factor that encourages the running of this UMKM well is that there is only 1 UMKM in the East Gapura Village, Sumenep Regency. While the inhibiting factor is the limited material used to make basket crafts not yet available in the nearest area.
\end{abstract}

Keywords : Community Empowerment, UMKM, Basket Craft

\begin{abstract}
ABSTRAK
Pemberdayaan adalah cara, proses, perbuatan memberdayakan. Sehingga pemberdayaan masyarakat dapat diartikan bahwa cara masyarakat berproses. Dalam hal ini, masyarakat berproses dalam UMKM. Proses yang dimaksud disini adalah proses untuk memperbaiki keadaan ekonomi masyarakat sekitar yang tidak stabil. Penelitian ini menggunakan pendekatan kualitatif dengan metode dengan metode deskriptif. Penelitian ini berlokasi di Desa Gapura Timur Kabupaten Sumenep. Teknik pengumpulan data yang digunakan melalui wawancara, observasi dan dokumentasi. Kesimpulan atau Verifikasi. Hasil yang diperoleh dari penelitian ini menunjukkan bahwa proses pemberdayaan masyarakat melalui UMKM Kerajinan Keranjang ini berjalan dengan baik. Faktor yang medorong berjalannya UMKM ini dengan baik yaitu karema UMKM ini hanya ada 1 di Desa Gapura Timur Kabupaten Sumenep. Sedangkan faktor penghambatnya adalah keterbatasan bahan yang digunakan untuk membuat kerajinan keranjang belum bisa didapatkan di daerah terdekat.
\end{abstract}

Kata Kunci: Pemberdayaan Masyarakat, UMKM, Kerajinan Keranjang

\section{PENDAHULUAN}

Penyebab masyarakat tidak mendapat pendidikan yang berkualitas, kesulitan untuk membiayai kesehatan rendahanya tabungan, serta kurangnya jaminan sosial dan perlindungan bagi keluarga, salah satunya adalah kemiskinan. Kemiskinan inilah yang menjadi masalah utama dalam pembangunan di Indonesia.

Untuk mengatasi kemiskinan serta untuk mengahadapi krisis ekonomi, salah satu yang paling berpotensi ialah UMKM (Usaha Mikro, Kecil, dan Menengah). Meskipun begitu, posisi UMKM dalam kegiatan ekonomi Indonesia masih menuai banyak persoalan. Keadaan ini disebabkan karena rendahnya pendidikan dan pengalaman pelaku usaha UMKM, kesulitan modal, dan akses untuk mendapatkan bahan baku yang berkualitas dengan harga yang terjangkau.

Namun, keberadaan UMKM tidak dapat dihindarkan dari masyarakat bangsa ini. 
Karena bagaimanapun, keberadaan UMKM juga sangat bermanfaat dalam hal pendistribusian pendapatan masyarakat. Di sisi lain, dengan adanya UMKM ini mampu menyerap tenaga kerja sehingga hal ini dapat mengurangi tingkat pengangguran. Disinilah terlihat bahwa UMKM mampu menjadi wadah bagi masyarakat untuk bekerja.

Salah satu bukti bahwa UMKM dapat membantu perekonomian masyarakat sekitar ialah UMKM Kerajinan Keranjang yang berada Di Desa Gapura Timur kabupaten Sumenep. Dimana UMKM ini memepekerjakan masyarakat sekitar yang tidak memiliki pekerjaan tetap. Selain itu, UMKM ini memiliki peluang yang cukup besar dalam memberdayakan masyarakat sekitar.

Para pekerja UMKM Kerajinan ini umumnya adalah ibu rumah tangga yang sebelumnya tidak memiliki pekerjaan diluar rumah, sehingga warga sekitar yang hanya berstatus ibu rumah tangga juga mendapat penghasilan tanpa harus bekerja dengan waktu dan tempat yang ditentukan dan tanpa harus meninggalkan kewajiban utamanya. Tak hanya itu saja manfaat yang dirasakan oleh para pekerja, pekerja yang tergabung dalam UMKM ini juga dapat membantu meringankan beban suami secara finansial, mengingat kembali pendapatan yang dihasilkan dari bertani ataupun pekerjaan lainnya tidak cukup untuk memnuhi kebutuhan hidup keluarga.

Semakin berkembangnya UMKM Kerajinan Keranjang ini, lama-kelamaan tidak hanya para ibu saja yang bekerja, tetapi para kepala keluarga juga dapat bergabung dalam UMKM Kerajinan Keranjang ini. Hal ini disebabkan melonjaknya permintaan produk kerajinan keranjang. Karena pada dasarnya pekerjaan ini tidak mengharuskan para pekerjanya untuk mengerjakan kerajinan ini di tempat UMKM, banyak warga sekitar yang meskipun memiliki pekerjaan utama seperti petani, guru honorer, pedagang ataupun lainnya memilih untuk bergabung dengan menjadikan pekerjaan ini sebagai pekerjaan sampingan. Selain pekerjaan ini dapat dikerjakan dirumah masing-masing juga yang pasti pekerja tersebut memiliki penghasilan tambahan dengan bergabungnya mereka di UMKM Kerajinan Keranjang ini.

Penelitian ini dilakukan bertujuan untuk mengetahui bagaimana pemberdayaan masyarakat pada UMKM Kerajinan Keranjang Desa Gapura Timur Kabupaten Sumenep.

\section{TINJAUAN PUSTAKA}

\section{Sumber Daya Manusia}

Sumber daya manusia merupakan salah satu faktor yang penting dalam suatu organisasi ataupun suatu usaha. Oleh karena itu sumber daya manusia harus dikelola dengan baik untuk meningkatkan efektivitas dan efisiensi prganisasi ataupun usaha. MSDM adalah suatu bidang manajemen yang khusus mempelajari hubungan dan peranan manusia dalam organisasi perusahaan.

Menurut Hasibuan (2019:10), MSDM adalah ilmu dan seni mengatur hubungan dan peranan tenaga kerja agar efektif dan efisien membantu terwujudnya tujuan perusahaan, karyawan, dan masyarakat. Perkembangan MSDM didorong oleh kemajuan peradaban, pendidikan, ilmu pengetahuan, dan tuntutan daya saing produksi barang atau jasa yang dihasilkan.

Peranan MSDM sangat menentukan bagi terwujudnya suatu tujuan. Sumber daya manusia selain mampu dan terampil, juga tidak kalah pentingnya kemauan dan kesungguhan mereka untuk bekerja efektif dan efisien. Kemampuan yang dimiliki kurang berarti apabila tidak diikuti moral 
kerja dan kedisiplinan karyawan dalam mewujudkan suatu impian.

\section{Pemberdayaan Masyarakat}

Menurut KBBI pemberdayaan adalah cara, proses, perbuatan memberdayakan. Sehingga pemberdayaan masyarakat dapat diartikan bahwa cara masyarakat berproses. Dalam hal ini, masyarakat berproses dalam UMKM. Proses yang dimaksud disini adalah proses untuk memperbaiki keadaan ekonomi masyarakat sekitar yang tidak stabil. Oleh karena itu adanya UMKM ini dapat membantu memberdayakan masyarakat sekitar guna memperbaiki keadaan ekonominya.

\section{Usaha Mikro, Kecil, dan Menengah (UMKM)}

Usaha Mikro, Kecil dan Menengah memiliki posisi penting dalam pemanfaatan sumber daya manusia dan pembangunan ekonomi. Khusunya di kawasan pedesaan, adanya UMKM sangat penting untuk mengurangi tingkat pengangguran yang ada. Penempatan karyawan yang jauh dibawah kemampuannya ataupun diluar kemampuannya mengakibatkan moral kerja dan kedisiplinan karyawan rendah (Hasibuan, 2019:28). Oleh sebab itu sistem pemilihan pekerjanya didasarkan pada ketelitian dan keuletan yang dimiliki. Dengan memiliki keuletan dan ketelitian para pekerja sesuai untuk dipekerjakan dalam UMKM Kerajinan Keranjang ini.

Dalam hal ini penempatan pekerja dapat sesuai dengan keahliannya. Jika seluruh proses seleksi telah ditempuh dan lamaran seseorang telah diterima, akhirnya seseorang memperoleh status sebagai pegawai dan ditempatkan pada posisi tertentu untuk melaksanakan tugas atau pekerjaan tertentu pula (Sunyoto, 2013:123). Satuan kerja yang mengelola sumber daya manusia merupakan satuan kerja penunjang terhadap semua satuan kerja lain dalam organisasi (Siagian, 2015:31).

Adanya UMKM Kerajinan ini guna sebagai penunjang kehidupan masyarakat. Banyak masyarakat sekitar yang memiliki pekerjaan yang tidak tetap atau hanya sebagai ibu rumah tangga saja. Sehingga dengan adanya UMKM ini ekonomi masyarakat sekitar sedikit terbantu. UMKM ini hanya memiliki beberapa pekerja saja. Meskti para pekerjanya tidak banyak, namun UMKM ini tetap berjalan. Bahkan pemilik yang selaku sebagai pengelola tak segan untuk turun tangan memproduksi produk yang ada dalam UMKM tersebut. Jumlah produk yang dihasilkan tidak tentu setiap harinya. Hal ini disebabkan karena keterbatasan pekerjanya.

Dalam lingkup pedesaan yang warganya terbatas dan keadaan ekonomi yang tidak dapat mencukupi kebutuhan ekonomi masyarakatnya, menyebabkan banyaknya warga yang lebih memilih untuk merantau ke kota-kota besar seperti ibu kota. Jumlah penduduk otomastis berkurang akibat pemikiran warga yang lebih baik merantau untuk memperbaiki keadaan ekonominya. Keberadaan warga semakin terbatas sehingga peminat untuk bekerja di UMKM ini juga sedikit. Hal ini yang menjadi penyebab tidak terpenuhinya target produksi yang diinginkan.

\section{METODOLOGI PENELITIAN}

Pendekatan yang dilakukan dalam penelitian ini adalah pendekatan kualitatif, yaitu metode deskriptif. Jenis data yang digunakan adalah data kualitatif dengan teknik pengumpulan data melalui observasi dan wawancara. Jenis data yang digunakan yaitu data subjek dan data fisik. Dengan sumber data yaitu data primer dan data sekunder. Adapun jumlah informan dalam penelitian ini sebanyak 7 orang, diantaranya yaitu 1 orang informan kunci (pemilik 
UMKM Kerajinan Keranjang), 3 orang informan utama (para pekerja UMKM Kerajinan Keranjang), dan 3 orang informan pendukung (masyarakat sekitar UMKM Kerajinan Keranjang). Informan tersebut diambil berdasarkan teknik pengambilan sampel. Teknik pengambilan sample yang digunakan dalam penelitian ini adalah Probability Sampling, dimana dalam teknik pengambilan sample ini memberikan kesempatan yang sama untuk setiap elemen populasi untuk menjadi sample. Teknik analisis data yang digunakan menurut Miles \& Huberman (1992:16) analisis terdiri dari tiga alur kegiatan yang terjadi secara bersamaan, yaitu 1). Reduksi data, 2). Penyajian data, 3). Kesimpulan atau Verifikasi.

Dalam uji keabsahan data, peneliti menggunakan uji kredibilitas data menurut Sugiono (2013) diantaranya yaitu :

1. Perpanjangan pengamatan, dengan perpanjangan pengamatan berarti peneliti kembali ke lapangan, melakukan pengamatan dan wawancara lagi dengan pemilik dan pengelola UMKM Kerajinan Keranjnag yang berada di Desa Gapura Timur Kabupaten Sumenep sehingga hubungan peneliti dengan narasumber akan semakin terbentuk, semakin akrab, semakin terbuka, saling percaya dan tidak ada informasi yang disembunyikan lagi;

2. Meningkatkan ketekunan, berguna agar pengamatan dilakukan secara lebih cermat dan berkesinambungan. Dengan cara ini kepastian data dan urutan peristiwa akan semakin akurat;

3. Trianggulasi, dalam pengujian kredibilitas dilakukan pengecekan data dengan berbagai cara dan waktu. Dengan pengujian ini peneliti dapat mengetahui bagaimana proses bekerja dalam UMKM Kerajinan Keranjang sehingga mereka yang terlibat mampu bekerjasama dengan baik dalam suatu UMKM. Data yang tersebut diperoleh setelah melakukan observasi serta wawancara antara peneliti dan pemilik UMKM tersebut.

\section{HASIL DAN PEMBAHASAN}

\section{Hasil}

Pemberdayaan Masyarakat Melalui UMKM Kerajinan Keranjang yag terletak di Desa Gapura Timur yang dilakukan sejauh ini sangat baik dan berangsur-angsur semakin meningkat. Ini terbukti karena semakin bertambahnya masyarakat yang ikut berpartisipasi dalam UMKM Kerajinan Keranjang ini. Berdirinya UMKM Kerajinan Keranjang ini sangat membantu masyarakat sekitar yang tidak memiliki pekerjaan atau yang membutuhkan pekerjaan sampingan untuk memenuhi kebutuhan hidupnya.

Pada dasarnya UMKM Kerajinan Keranjang ini didirikan untuk membantu masyarakat sekitar. Maka dengan adanya UMKM Kerajinan Keranjang ini kehidupan ekonomi masyarakat sekitar dapat terbantu, secara tidak langsung juga dapat mengenalkan produk yang dihasilkan oleh Desa Gapura Timur. Jadi berdirinya UMKM Kerajinan Keranjang ini tidak hanya menguntungkan pemiliknya saja, tetapi juga dapat berguna bagi masyarakat sekitar ketika masyarakat yang membutuhkan pekerjaan ikut bergabung dalam UMKM Kerjainan Keranjang ini.

\section{Pembahasan}

UMKM pada umumnya mengandalkan modal sendiri dalam menjalankan usahanya, dan terkadang mereka terjebak dengan keterikatan rentenir mengingat masih rendahnya aksesbilitas terhadap sumber-sumber pembiayaan formal. Penelitian ini dilakukan dengan pendekatan kualitatif dengan metode deskriptif. Dimana 
data yang diperoleh bersifata apa adanya. Dengan rentang waktu selama kurang lebih 4 bulan, peneliti berusaha semaksimal mungkin agar penelitian ini selesai tepat waktu. UMKM Kerajinan Keranjang ini didirikan untuk memberdayakan masyarakat sekitar yang membutuhkan pekerjaan.

Rata-rata pekerjanya memiliki pekerjaan utama. sehingga pekerjaan ini hanya dijadikan sebagai pekerjaan sampingan saja. Ekonomi masyarakat sangat terbantu ketika memilih untuk bekerja dalam UMKM Kerajinan Keranjang ini. Karena penghasilan mereka pasti bertambah. Dan dalam UMKM Kerajinan Keranjang ini masyarakat bisa kapan saja meminta bayaran atau upah atas kerja keras mereka. Ibu Halilah mengerti akan keadaan ekonomi serta kebutuhan masyarakat sekitarnya. Oleh sebab itu, Ibu Halilah membebaskan para pekerjanya untuk meminta upah kapan saja yang mereka mau. Karena upah atau bayaran yang mereka terima berpatokan pada seberapa banyak hasil produk yang telah mereka selesaikan. Jadi para pekerja bisa memperkirakan berapa banyak penghasilan yang akan mereka terima. Bahan yang digunakan dalam pembuatan kerajinan keranjang anyaman ini adalah berbahan dasar plastik. Yaitu sebuah tali yang biasanya digunakan sebagai untuk mengikat karung.

Bahan ini tersedia dalam bentuk gulungan panjang. Untuk memproses bahan mentah untuk menjadi bahan jadi harus melalui proses pengukuran dan pemotongan tali tersebut kemudian menganyamnya hingga menjadi sebuah keranjang. UMKM Kerajinan Keranjang yang hanya ada satu di Desa Gapura Timur menjadikannya sangat efektif untuk memberdayakan masyarakat sekitar dimana tingkat ekonomi rata-rata warga desa ini masih rendah. Sehingga mereka membutuhkan penghasilan tambahan agar kebutuhan hidupnya dapat terpenuhi. Hal tersebut sangat sesuai dengan tujuan didirikannya UMKM Kerajinan Keranjang ini, dimana yang menjadi sasaran sebagai pekerjanya adalah masyarakat sekitar.

\section{KESIMPULAN DAN SARAN}

\section{Kesimpulan}

Berdasarkan penelitian yang yang telah peneliti lakukan mengenai Pemberdayaan Masyarakat Melalui UMKM Kerajinan Keranjang Di Desa Gapura Timur Kabupaten Sumenep. Maka dapat disimpulkan bahwa UMKM dapat membantu perekonomian benar adanya. Berdirinya UMKM sedikit banyak juga membantu mengurangi tingkat pengangguran terutama bagi masyarakat sekitar. Pemberdayaan masyarakat melalui UMKM Kerajinan Keranjang ini berjalan dengan baik bahkan semakin lama semakin ada peningkatan. Pemberdayaan masyarakat melalui UMKM Kerajinan Keranjang ini terbukti dengan para pekerjanya yang merupakan masyarakat sekitar yang tidak memiliki pekerjaan tetap. Hal ini membuktikan bahwa pemberdayaan masyarakat yang dilakukan dapat terlaksana sesuai dengan sebagaimana mestinya.

\section{Saran}

Saran yang ingin peneliti berikan tidak lain hanya sekedar memberi masukan dengan harapan Pemberdayaan UMKM Melalui Kerajinan Keranjang Di Desa Gapura Timur Kabupaten Sumenep ini dapat terus berlanjut sehingga semakin banyak membantu masyarakat sekitar yang membutuhkan pekerjaan. Saran yang peneliti ingin berikan adalah :

a. Perlunya pelatihan yang tepat agar produk yang dihasilkan tidak hanya satu model saja, tetapi bervariasi sehingga para konsumen semakin tertarik pada produk yang dihasilkan. 
b. Perlu adanya target dalam sehari untuk setiap orang agar produk yang dihasilkan dapat menyesuaikan dengan permintaan pasar atau permintaan konsumen.

c. Mencari bahan baku yang lebih mudah didapat dan terjangkau apabila bahan baku yang biasa digunakan terasa sulit didapat dengan harga yang lebih mahal.

d. Mengajak lebih banyak masyarakat sekitar untuk ikut serta bergabung dalam UMKM Kerajinan Keranjang, agar produk yang dihasilkan dapat memenuhi permintaan pasar ataupun permintaan konsumen.

e. Perlu adanya keterlibatan pemerintah daerah dalam melakukan pembinaan kepada para pelaku UMKM.

f. Perlu adanya pejadwalan dalam melakukan pelatihan agar tidak mengganggu proses bekerja dalamUMKM

\section{DAFTAR PUSTAKA}

Hasibuan, M.S.P. (2019). Manajemen Sumber Daya Manusia, Edisi Revisi. PT Bumi Aksara. Jakarta.

Siagian, S.P. (2015). Manajemen Sumber Daya Manusia. PT Bumi Aksara. Jakarta.

Sugiyono.(2013). Metode Penelitian Manajemen Kuantitatif, Kualitatif, dan R\&D. Bandung: Alfabet. CV.

Sunyoto, D. (2013). Manajemen Sumber Daya Manusia. CAPS. Yogyakarta. 